\title{
Temporal and Spatial Variability of Air Temperatures in Estonia during 1756-2014
}

\author{
Agu Eensaar \\ Centre of Real Sciences, Tallinn University of Applied Sciences, Pärnu Maantee 62, 10135 Tallinn, Estonia \\ Correspondence should be addressed to Agu Eensaar; agu.eensaar@gmail.com
}

Received 22 October 2015; Accepted 24 December 2015

Academic Editor: Pedro Ribera

Copyright (C) 2016 Agu Eensaar. This is an open access article distributed under the Creative Commons Attribution License, which permits unrestricted use, distribution, and reproduction in any medium, provided the original work is properly cited.

\begin{abstract}
The change in the statistical and temporal parameters of air temperatures in the Estonian cities, that is, Tallinn and Tartu, was analyzed for two centuries. The results showed that the change of air temperature in Estonia exceeded $0.5^{\circ} \mathrm{C}$ per ten years for the time 1979-2012. For the longer period, that is, 1880-2012, the average annual rise in the air temperature was within the range of $0.1^{\circ} \mathrm{C}$ per ten years. The analysis of frequency distributions of the average annual air temperatures and Welch's $t$-test demonstrated the considerable rise in air temperature (the significance level of 0.05) in Estonia, which took place in 1901-2014 and was witnessed only in the months from November to April. However, no significant rise in air temperature was detected in Estonia from May to October.
\end{abstract}

\section{Introduction}

Climate change has a considerable impact on the natural environment and human activities that can differ by regions. The relevance of the issue is based on the fact that the Intergovernmental Panel on Climate Change (IPCC) was established in 1988 by the World Meteorological Organization (WMO) and the United Nations Environment Programme (UNEP) with the aim to provide a comprehensive assessment of all aspects of climate change [1].

To forecast climate change and its impact, the peculiarities in the changes of various components related to the climate need to be examined. One of the significant parameters characterizing climate change is the air temperature. Global warming, verified by recent studies [2], is one of the major global concerns. In addition, it is also essential to study the changes in air temperature at local or regional level. Several studies have been dedicated towards the examination of climate change in the Baltic Sea regions [3-5]. The major cities in Estonia include Tallinn, the capital city, with ca. 430 thousand residents, and Tartu, with ca. 100 thousand residents (Figure 1). Therefore, it is significantly important to examine the peculiarities of the climate change of these cities. The present study aims at investigating the trends and variability in air temperatures in Estonian cities, such as Tallinn and Tartu, during 1756-2014.

\section{Data and Methods}

The use of instrumental measurements that were organized by a network of systematically arranged weather stations started in Estonia in the middle of the 19th century. Prior to this period, the meteorological observations were performed by individuals. Instrumental observations during the 18th century and the first-half of the 19th century in Estonia were performed using various measuring instruments. In addition, no uniform observation rules were followed during that period [6]. Therefore, it is difficult to estimate the accuracy of earlier observations. So far, the first known regular meteorological observations in Tallinn were performed in the years 1777-1779 by an artillerist named Breckling [6]. Professor Carpov of Schola cathedralis Tallinnensis (Tallinn Cathedral School) performed meteorological observations in the years 1779-1800 [7]. Later, Ivanov, Rickers, Schieferdecker, and other naval officers of the Port of Tallinn acted as single observers [8]. There are also additional miscellaneous indirect data concerning the meteorological situation of the earlier period [9]. Observations, made by enthusiasts, differ 


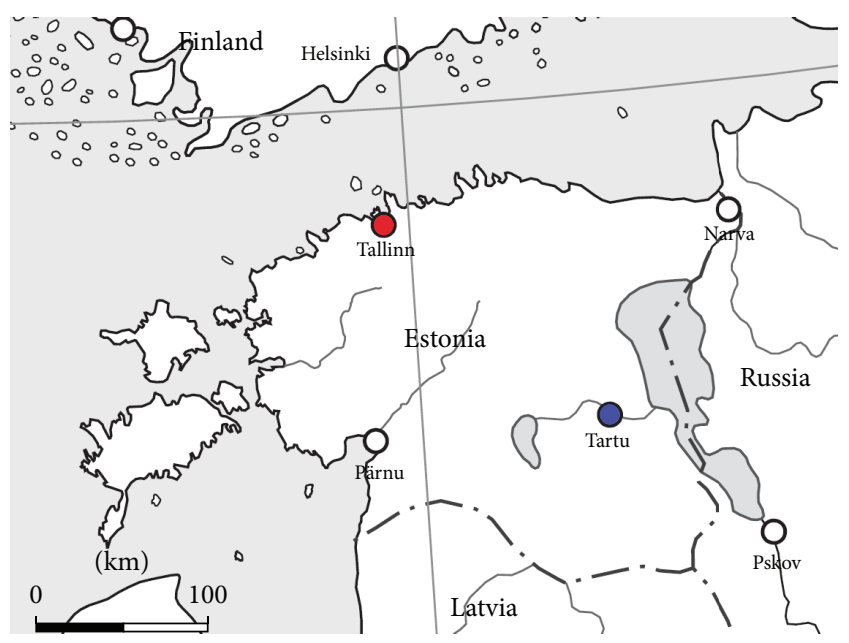

Figure 1: Map of Estonia.

considerably in their quality; yet after critical analysis this data appears more precise than any reconstruction made on the basis of indirect data. Due to the unavailability of local regular observations, Tarand [10] reconstructed the average monthly air temperatures in Tallinn for the period of 17561804 using the air temperature data of the nearby cities (i.e., St. Petersburg, Russia; Stockholm, Sweden; Loviisa and Porvoo, Finland). When comparing the data, taking into consideration the different level of industrialization in these cities, it has been concluded that the trend of global warming in the Nordic region is $0.8^{\circ} \mathrm{C}$ per 100 years and the urban heat island effect of most of the cities is $0.4^{\circ} \mathrm{C}$ per 100 years. In addition to that, Tarand et al. [8] has established that there is a great likelihood that many of the air temperature observations concerning summer and dating from the second half of the 18th century and the beginning of the 19th century have been influenced by the direct solar radiation effect common only to the countries in the Nordic region.

The ice data of the Port of Tallinn were also used as the essential supporting data. In the period of 1805-1849, simultaneous observations were taken at two locations in Tallinn. Neither of the two basic air temperature measuring areas in Estonia (Tallinn and Tartu) succeeded in organizing observations at the same location for a longer period. Thus, the air temperature has been measured at seven different locations in Tallinn and nine locations in Tartu. Based on parallel observations, Tarand et al. [8] found the location corrections, taking into account the effects of mesoclimate on the results of temperature measurements of meteostations located on the territories of Tallinn and Tartu. He used the location corrections and results from the earlier and later systematic meteorological observations at several observation points for the reconstruction of a time-series of average monthly air temperatures in Tallinn in the years 1756-2000, which was reduced to the TallinnMaarjamäe observation point (N $59^{\circ} 27^{\prime} 24^{\prime \prime}$; E $\left.24^{\circ} 48^{\prime} 50^{\prime \prime}\right)$. For the time being, the air temperatures in Tallinn were measured at the Tallinn-Harku meteorological station of the Estonian Weather Service (N $59^{\circ} 23^{\prime} 53^{\prime \prime}$; E $24^{\circ} 36^{\prime} 10^{\prime \prime}$ ), which

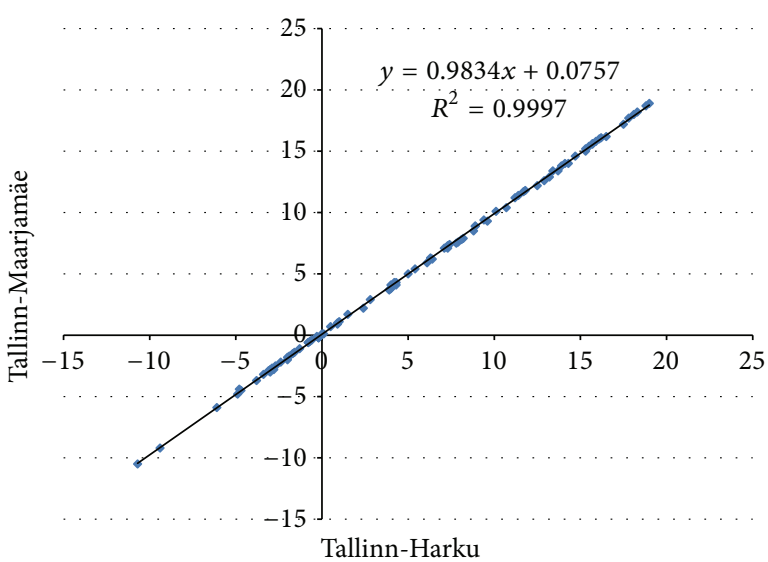

FIgURE 2: Relationship between the average monthly air temperatures $\left({ }^{\circ} \mathrm{C}\right)$ in Tallinn-Maarjamäe and Tallinn-Harku.

later published the results of meteorological observations in yearbooks, the latest being in 2013 [11]. The data of Estonian weather observations are stored in the databases of Statistics Estonia (SE) (http://www.stat.ee/en), which collects and stores data according to the international classifications and methods. At present, the meteorological station in Maarjamäe is no longer operative; hence, there is a lack of direct measuring data of air temperatures. The parallel data of air temperatures of Tallinn-Maarjamäe and Tallinn-Harku during 1992-2000 was used to determine the mutual relationship between the average monthly air temperatures of the observation points (Figure 2). Based on the relationship, the temperatures measured in the years 2001-2014 at the TallinnHarku meteorological station were reduced to the TallinnMaarjamäe observation point. This provided an opportunity to extend Tarand's et al. [8] time-series of average monthly temperatures until the end of 2014.

The air temperature data of Tartu were recorded from 1821 onwards using J. F. Parrot's observations $[12,13]$. By using the location corrections found for different observation points and the results of meteorological observations performed at various observation points in Tartu, Tarand et al. [8] reconstructed a time-series of average monthly air temperatures in Tartu for the years 1821-1999, which was reduced to the TartuTõravere meteorological station ( $58^{\circ} 15^{\prime} 51^{\prime \prime}$; E $26^{\circ} 27^{\prime} 41^{\prime \prime}$ ). Presently, the meteorological observations are taken at the Tõravere meteorological station of the Estonian Weather Service. Therefore, no correction factors have been used while extending Tarand's et al. [8] time-series of temperatures in Tartu until to 2014.

The changes in air temperature were analyzed in Tallinn during the years 1756-2014 and in Tartu during 1821-2014. The average monthly air temperatures analyzed were found to originate from the monograph [8] to which the average air temperatures (until the year 2014) found from the data available in the SE database of measurements of the Estonian Weather Service were added.

The meteorological conditions are formed due to a multitude of factors that make it difficult to determine a causeand-effect relationship, which is only possible in the case of 


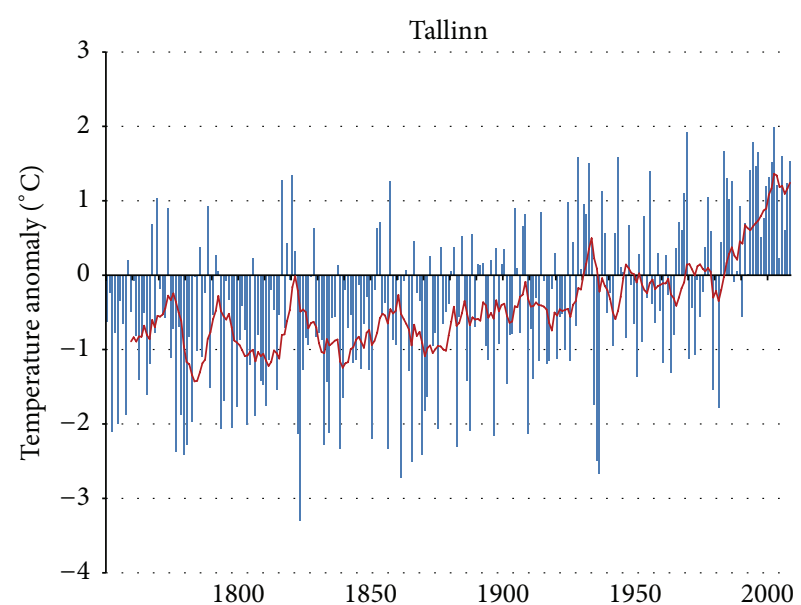

(a)

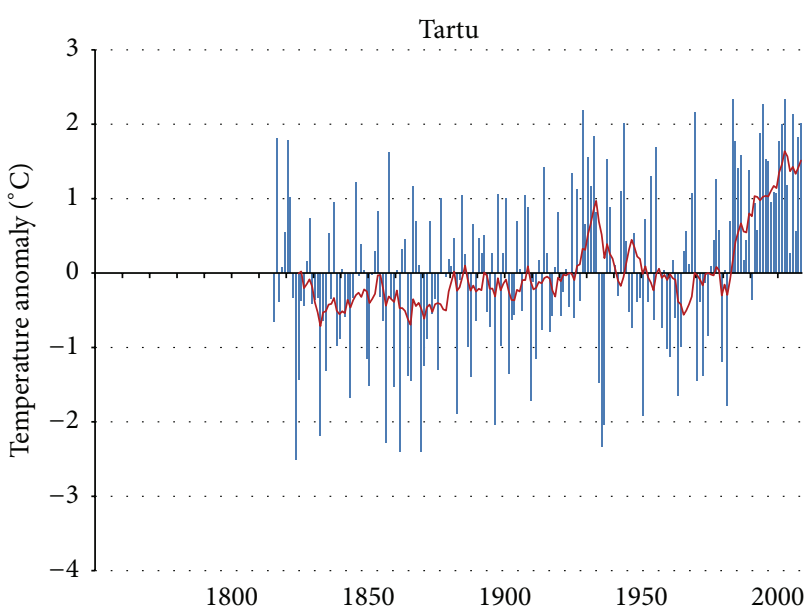

(b)

Figure 3: Mean temperature annual anomalies (difference in relation to the 1961-1990 average): (a) Tallinn in years 1756-2014; (b) Tartu in years 1821-2014. The decadal moving average is presented by the red line.

a specific situation. However, every specific meteorological situation may be regarded as a realization of every possible meteorological condition at a given location that has some probability of occurrence. In the course of time, given the large variability of air temperatures, statistical methods are used in this research for finding out the parameters that characterize the change in air temperature [14].

\section{Results and Discussion}

3.1. Average Annual Air Temperatures. Firstly, the change of air temperatures over a long period is of interest. The average annual air temperature, represented by $t_{y}$, was calculated as the weighted average of the average monthly temperatures:

$$
t_{y}=\frac{\sum_{i} n_{i} t_{i}}{\sum_{i} n_{i}}
$$

where $i$ is the consecutive number of the month, $n_{i}$ is the number of days in the month $i$, and $t_{i}$ is the average temperature of the month $i$.

The average annual temperature (1) depends on the locality and fluctuates significantly with time. Therefore, in order to compare the variability and trends of the temperatures of various localities, it is important to examine the fluctuations in relation to the average value of a certain period. Figure 3 shows the fluctuations (anomalies) of the average annual air temperatures in relation to the average air temperatures of 1961-1990. The figure also shows the moving decade averages of the temperature fluctuations.

Figure 3 confirms that the average annual temperatures in Tallinn and Tartu vary to a great extent. The annual temperatures have changed (in relation to 1961-1990 average) from $-3.3^{\circ} \mathrm{C}$ to $+2.0^{\circ} \mathrm{C}$ in Tallinn and from $-2.5^{\circ} \mathrm{C}$ to $+2.0^{\circ} \mathrm{C}$ in Tartu. In the past few years, the air temperatures in both Tallinn and Tartu revealed a strong rising trend.

There is a rather strong correlative relationship between the average annual air temperatures in Tallinn and Tartu

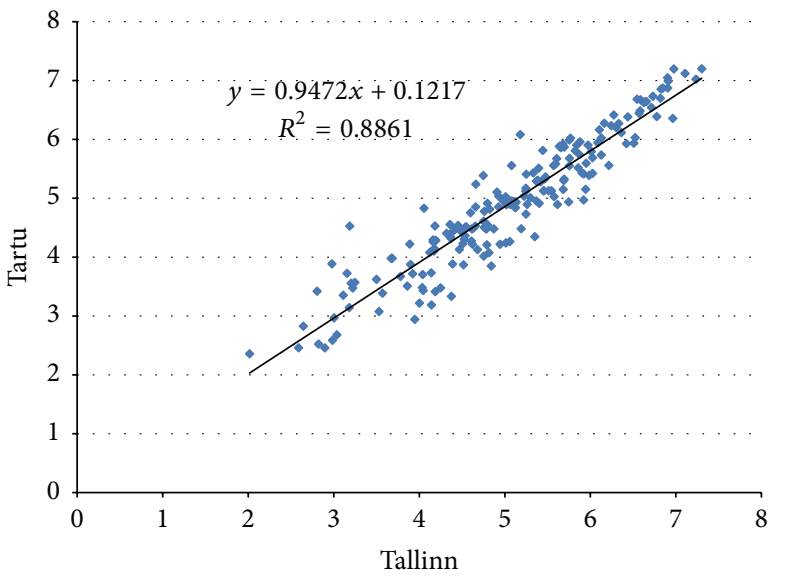

FIGURE 4: The relationship between the average annual air temperatures $\left({ }^{\circ} \mathrm{C}\right)$ in Tallinn and Tartu for the years 1821-2014.

(Figure 4). Thereby the value of linear correlation coefficient is 0.94 .

Due to their greater variability, the annual average air temperatures can be considered as random variables characterized by a distribution function. The average air temperature values occur with greater probability and are more extreme with a smaller probability. The change of the mean value and variance of the distribution function of air temperature for longer periods is a variable characteristic of climate change. When calculating the frequency distributions, we have divided the analyzed data into three groups by the centuries: 18th, 19th, and 20th centuries together with the 21st century.

Figure 5 presents the frequency distributions (in percentage) of average annual air temperatures in Tallinn and Tartu in different periods. The Jarque-Bera test was used to test the normality of the data. 


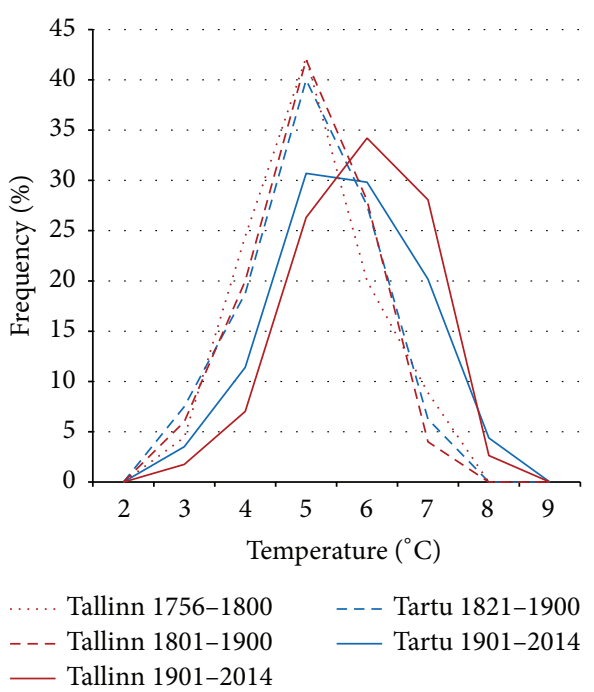

FIGURE 5: Frequency distributions of average annual air temperatures in Tartu and Tallinn in various periods per $1^{\circ} \mathrm{C}$ intervals.

Figure 5 shows the average annual air temperature data that follows the normal distribution with $95 \%$ level of confidence. It appears that no significant change has taken place in Tallinn during 1801-1900 compared to the earlier period of 1756-1800. However, the distributions have shifted nearly $1^{\circ} \mathrm{C}$ in the positive direction in both Tallinn and Tartu during 1901-2014 compared to the earlier periods. This means that the average annual air temperature has risen considerably during the later periods.

In order to assess the nature of the change of Estonian average annual air temperatures, the trends in the changes in Tallinn and Tartu for 10 years per five customarily compared periods and the method of least squares [13] were considered as the basis of the calculations. The trends of global land surface air temperature [2] and air temperature data from Central England $[15,16]$ were used as references (Figure 6).

It becomes evident from Figure 6 that the rise of the average annual air temperature in Estonia has been faster than it has been global, especially in the later periods, reaching even $0.5^{\circ} \mathrm{C}$ per ten years. At the same time, the rise in the longer period of $1880-2012$ is still closer to the global trend, remaining within the range of $0.1^{\circ} \mathrm{C}$ per ten years.

3.2. Average Monthly Air Temperatures. Since Tallinn is situated on the sea and Tartu lies inland, the differences in air temperature during the year are rather large. It becomes evident from Figure 7 that the average monthly temperature in Tallinn in autumn and winter (from September to March) is higher than that of Tartu, with a difference reaching up to $1.6^{\circ} \mathrm{C}$. In spring and summer (from April to August), the average monthly air temperature in Tartu is higher up to $2^{\circ} \mathrm{C}$.

Despite the geographical proximity, the temporal course of air temperatures is different in Tallinn and Tartu. Therefore, they both need to be considered when analyzing the Estonian temperature regime.

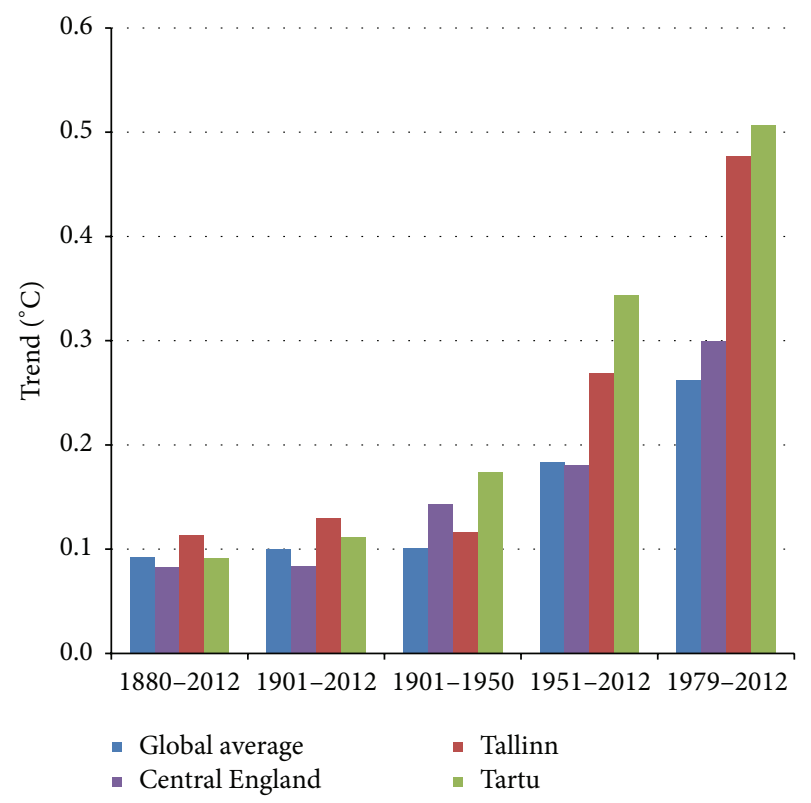

Figure 6: Annual average air temperature trends per decade.

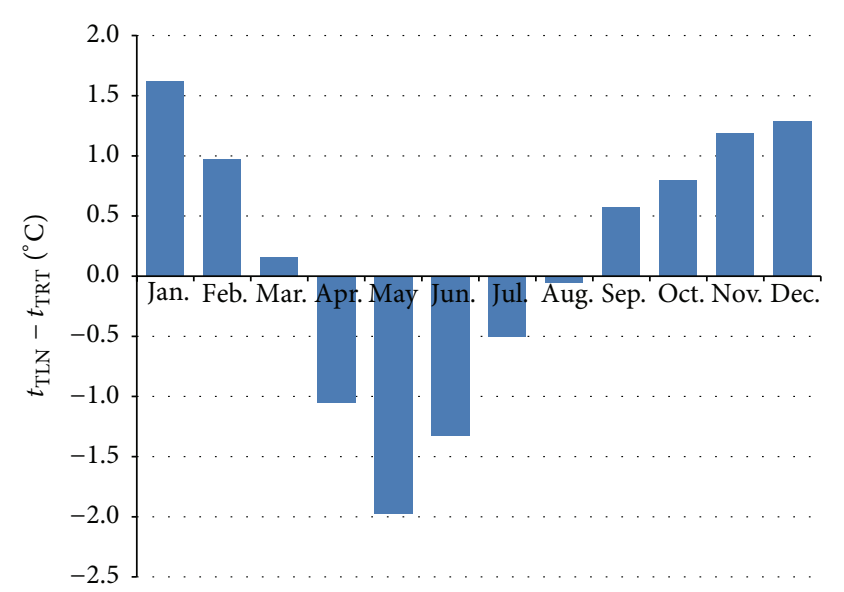

FIgURE 7: The difference between the average air temperatures in 1821-2014 in Tallinn compared to Tartu $\left(t_{\mathrm{TLN}}-t_{\mathrm{TRT}}\right)$.

The fast change of air temperature in Estonia poses a threat to its natural resources and, thus, its features need to be examined in detail. The average monthly air temperature also depends on many circumstances and can be regarded as a random variable and treated statistically. Every meteorological situation has its causes and a course that results from it; however, due to the complexity of the cause-and-effect relationship, such kind of analysis is difficult to perform.

Figure 8 presents the frequency distribution of the occurrence of all average monthly air temperatures in Tallinn (1756-2014) and Tartu (1821-2014). The percentages are calculated for $1^{\circ} \mathrm{C}$ intervals. The frequency distributions of all monthly air temperatures in Central England in the years 1756-2014 that are calculated on the basis of a previous study's [11] data are used for reference basis. It is evident that the frequency of occurrence of the average monthly temperatures 
TABLE 1: Statistical indicators of the average air temperatures $\left({ }^{\circ} \mathrm{C}\right)$ in Tallinn by periods of time.

\begin{tabular}{|c|c|c|c|c|c|c|c|c|c|c|c|c|c|c|}
\hline Indicator & Period & Jan. & Feb. & Mar. & Apr. & May & Jun. & Jul. & Aug. & Sep. & Oct. & Nov. & Dec. & Year \\
\hline \multirow{4}{*}{ Median } & $1756-1800$ & -6.6 & -5.4 & -3.0 & 2.2 & 7.4 & 13.2 & 16.2 & 15.3 & 11.4 & 6.2 & 1.2 & -4.1 & 4.6 \\
\hline & $1801-1900$ & -5.6 & -6.0 & -3.2 & 1.9 & 7.9 & 13.3 & 16.4 & 15.2 & 11.3 & 6.0 & 0.6 & -2.9 & 4.6 \\
\hline & 1901-2014 & -3.8 & -4.8 & -1.6 & 3.4 & 9.0 & 13.5 & 16.6 & 15.7 & 11.4 & 6.4 & 1.4 & -2.2 & 5.4 \\
\hline & $1756-2014$ & -5.3 & -5.4 & -2.7 & 2.5 & 8.4 & 13.4 & 16.5 & 15.4 & 11.4 & 6.2 & 1.1 & -2.6 & 4.8 \\
\hline \multirow{4}{*}{ Average } & $1756-1800$ & -6.6 & -5.9 & -4.0 & 2.0 & 7.5 & 13.4 & 16.5 & 15.6 & 11.7 & 6.1 & 1.0 & -3.5 & 4.5 \\
\hline & $1801-1900$ & -5.9 & -6.1 & -3.4 & 1.9 & 7.8 & 13.3 & 16.3 & 15.5 & 11.3 & 5.9 & 0.6 & -3.4 & 4.5 \\
\hline & $1901-2014$ & -4.5 & -5.1 & -2.0 & 3.4 & 8.9 & 13.7 & 16.8 & 15.6 & 11.4 & 6.3 & 1.4 & -2.2 & 5.4 \\
\hline & $1756-2014$ & -5.4 & -5.6 & -2.9 & 2.6 & 8.2 & 13.5 & 16.6 & 15.6 & 11.4 & 6.1 & 1.0 & -2.9 & 4.9 \\
\hline \multirow{4}{*}{ St. dev. } & $1756-1800$ & 3.2 & 3.4 & 3.1 & 1.7 & 1.6 & 1.3 & 1.5 & 1.3 & 1.5 & 2.1 & 2.3 & 2.9 & 0.9 \\
\hline & $1756-2014$ & 3.6 & 3.6 & 2.8 & 1.9 & 1.9 & 1.6 & 1.6 & 1.5 & 1.4 & 1.8 & 2.1 & 2.9 & 1.1 \\
\hline & $1801-1900$ & 3.7 & 3.5 & 2.6 & 1.8 & 1.9 & 1.7 & 1.5 & 1.6 & 1.3 & 1.7 & 2.0 & 3.0 & 1.0 \\
\hline & 1901-2014 & 3.4 & 3.7 & 2.7 & 1.8 & 1.7 & 1.6 & 1.6 & 1.4 & 1.4 & 1.8 & 2.0 & 2.8 & 1.0 \\
\hline \multirow{4}{*}{ Max. } & $1756-1800$ & 0.2 & 0.4 & 1.0 & 5.4 & 11.6 & 17.0 & 19.8 & 18.7 & 15.4 & 10.2 & 5.8 & 1.8 & 6.4 \\
\hline & $1801-1900$ & 0.6 & 0.3 & 2.1 & 6.6 & 12.6 & 16.8 & 20.3 & 20.5 & 14.6 & 9.9 & 4.7 & 1.3 & 6.7 \\
\hline & 1901-2014 & 1.8 & 2.5 & 3.0 & 7.1 & 12.9 & 17.5 & 21.2 & 19.6 & 14.9 & 9.6 & 5.3 & 4.4 & 7.3 \\
\hline & $1756-2014$ & 1.8 & 2.5 & 3.0 & 7.1 & 12.9 & 17.5 & 21.2 & 20.5 & 15.4 & 10.2 & 5.8 & 4.4 & 7.3 \\
\hline \multirow{4}{*}{ Min. } & $1756-1800$ & -13.4 & -16.1 & -9.9 & -2.8 & 4.8 & 11.2 & 13.2 & 13.1 & 9.4 & 1.2 & -6.5 & -13.0 & 2.9 \\
\hline & $1801-1900$ & -14.5 & -16.6 & -9.7 & -2.4 & 1.9 & 9.0 & 12.5 & 12.2 & 8.7 & 0.7 & -4.3 & -12.4 & 2.0 \\
\hline & $1901-2014$ & -15.2 & -14.3 & -9.9 & -1.1 & 4.4 & 9.8 & 13.2 & 12.6 & 7.1 & 1.8 & -4.8 & -9.2 & 2.6 \\
\hline & $1756-2014$ & -15.2 & -16.6 & -9.9 & -2.8 & 1.9 & 9.0 & 12.5 & 12.2 & 7.1 & 0.7 & -6.5 & -13.0 & 2.0 \\
\hline
\end{tabular}

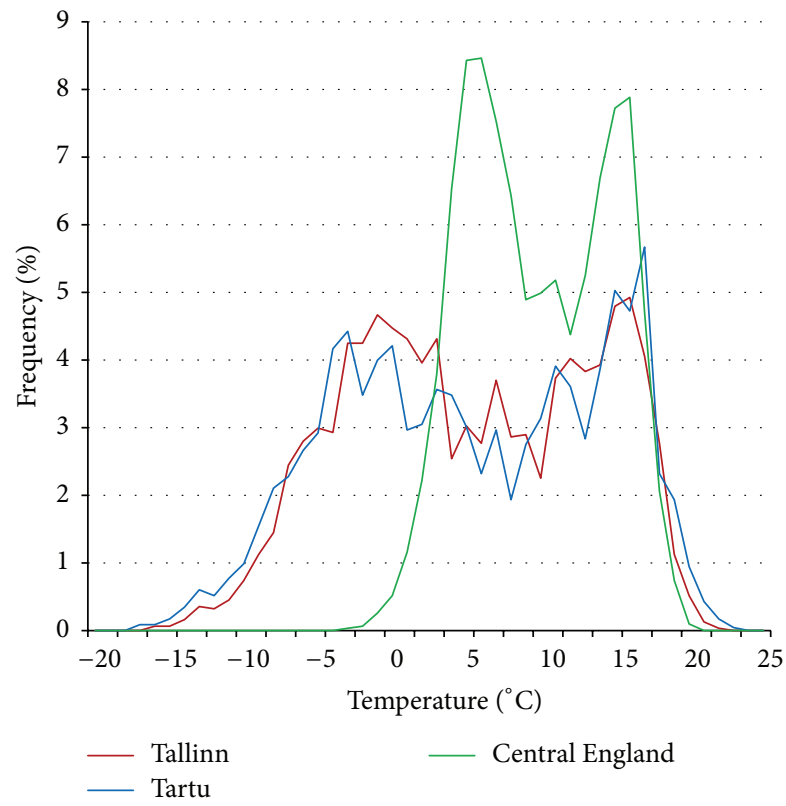

FIGURE 8: Frequency distribution of all the average monthly air temperatures in the years 1756-2014.

above $17^{\circ} \mathrm{C}$ in Estonia and that in Central England practically coincide. However, in Estonia, the air temperature changes to a much wider extent than in Central England with a significant difference concerning lower temperatures. In Estonia, the low air temperatures occur at a quite high frequency, hence indicating no significant difference in the situations of Tallinn and Tartu.
Firstly, we are interested in how the average monthly air temperature has changed over the time since the average annual air temperature forms as the weighted average of the average monthly air temperatures. Table 1 presents the statistical indicators (median, average, standard deviation, minimum value, and maximum value) of the average air temperatures in Tallinn, and Table 2 presents those in Tartu in various periods (centuries).

It becomes evident from Tables 1 and 2 that the changes in air temperatures are not homogeneous in all the months during the periods of observation. Thus, for example, the average temperature in January in different centuries has risen from $-6.6^{\circ} \mathrm{C}$ to $-4.5^{\circ} \mathrm{C}$ in Tallinn and from $-7.4^{\circ} \mathrm{C}$ to $-6.1^{\circ} \mathrm{C}$ in Tartu. However, the average air temperatures in September have fallen from $11.7^{\circ} \mathrm{C}$ to $11.4^{\circ} \mathrm{C}$ in Tallinn and from $10.9^{\circ} \mathrm{C}$ to $10.8^{\circ} \mathrm{C}$ in Tartu. The average monthly air temperatures in Estonia vary to a great extent, changing in the range up to $20^{\circ} \mathrm{C}$. The variability of air temperatures in different months is worthy of closer examination. The main issue of interest lies with the frequency distributions of air temperature (occurrence frequencies of various temperatures) in different months and how and whether these distributions have changed over centuries. We observed the frequency distributions of average monthly temperatures both in Tallinn and Tartu in various periods (centuries) in order to find out the nature of change of the air temperature.

Figure 9 presents the frequency distributions of average monthly air temperatures in Tallinn and Tartu. In the case of Tallinn, the distributions of the air temperatures in January and February and those of December and March virtually coincide. In the case of Tartu, the distributions of the air temperatures in January and February and those of May and 
TABLE 2: Statistical indicators of the average air temperatures $\left({ }^{\circ} \mathrm{C}\right)$ in Tartu by periods of time.

\begin{tabular}{lcccccccccccccc}
\hline Indicator & Period & Jan. & Feb. & Mar. & Apr. & May & Jun. & Jul. & Aug. & Sep. & Oct. & Nov. & Dec. & Year \\
\hline \multirow{3}{*}{ Median } & $1821-1900$ & -7.1 & -6.6 & -3.4 & 3.1 & 10.3 & 15.2 & 17.1 & 15.4 & 10.9 & 5.2 & -0.8 & -4.4 & 4.5 \\
& $1901-2014$ & -5.3 & -6.0 & -1.8 & 4.3 & 10.7 & 14.6 & 16.9 & 15.7 & 10.8 & 5.5 & 0.5 & -3.4 & 4.9 \\
& $1821-2014$ & -6.4 & -6.3 & -2.6 & 3.7 & 10.5 & 14.9 & 16.9 & 15.6 & 10.8 & 5.4 & -0.1 & -3.7 & 4.8 \\
\hline \multirow{3}{*}{ Average } & $1821-1900$ & -7.4 & -6.9 & -3.3 & 3.2 & 10.1 & 15.2 & 17.2 & 15.6 & 10.9 & 5.3 & -0.7 & -4.8 & 4.5 \\
& $1901-2014$ & -6.1 & -6.2 & -2.4 & 4.4 & 10.7 & 14.7 & 17.1 & 15.6 & 10.8 & 5.4 & 0.3 & -3.2 & 4.9 \\
& $1821-2014$ & -6.6 & -6.5 & -2.7 & 3.9 & 10.5 & 14.9 & 17.1 & 15.6 & 10.8 & 5.3 & -0.1 & -3.9 & 4.8 \\
\hline \multirow{3}{*}{ St. dev. } & $1821-1900$ & 3.9 & 3.5 & 2.7 & 1.9 & 2.2 & 1.6 & 1.9 & 1.5 & 1.5 & 1.8 & 2.3 & 3.0 & 1.0 \\
& $1901-2014$ & 4.0 & 3.8 & 3.0 & 2.1 & 2.1 & 1.7 & 1.9 & 1.5 & 1.6 & 1.9 & 2.3 & 3.2 & 1.1 \\
& $1821-2014$ & 3.9 & 4.0 & 3.1 & 2.1 & 2.0 & 1.7 & 1.9 & 1.5 & 1.6 & 1.9 & 2.3 & 3.3 & 1.1 \\
\hline \multirow{3}{*}{ Max. } & $1821-1900$ & 0.0 & 0.0 & 1.9 & 7.7 & 15.1 & 19.0 & 21.9 & 19.8 & 14.7 & 8.4 & 4.3 & 0.3 & 6.6 \\
& $1901-2014$ & 1.7 & 2.4 & 4.4 & 9.3 & 18.3 & 19.2 & 22.6 & 20.2 & 14.7 & 8.9 & 4.2 & 3.3 & 7.2 \\
& $1821-2014$ & 1.7 & 2.4 & 4.4 & 9.3 & 18.3 & 19.2 & 22.6 & 20.2 & 14.7 & 8.9 & 4.3 & 3.3 & 7.2 \\
\hline \multirow{3}{*}{ Min. } & $1821-1900$ & -17.0 & -17.6 & -9.6 & -0.5 & 3.8 & 10.6 & 11.0 & 12.4 & 7.3 & -0.3 & -5.5 & -14.2 & 2.3 \\
& $1901-2014$ & -16.6 & -15.5 & -10.8 & -0.9 & 6.4 & 10.9 & 10.6 & 12.4 & 6.6 & 0.0 & -6.8 & -13.4 & 2.5 \\
& $1821-2014$ & -17.0 & -17.6 & -10.8 & -0.9 & 3.8 & 10.6 & 10.6 & 12.4 & 6.6 & -0.3 & -6.8 & -14.2 & 2.3 \\
\hline
\end{tabular}

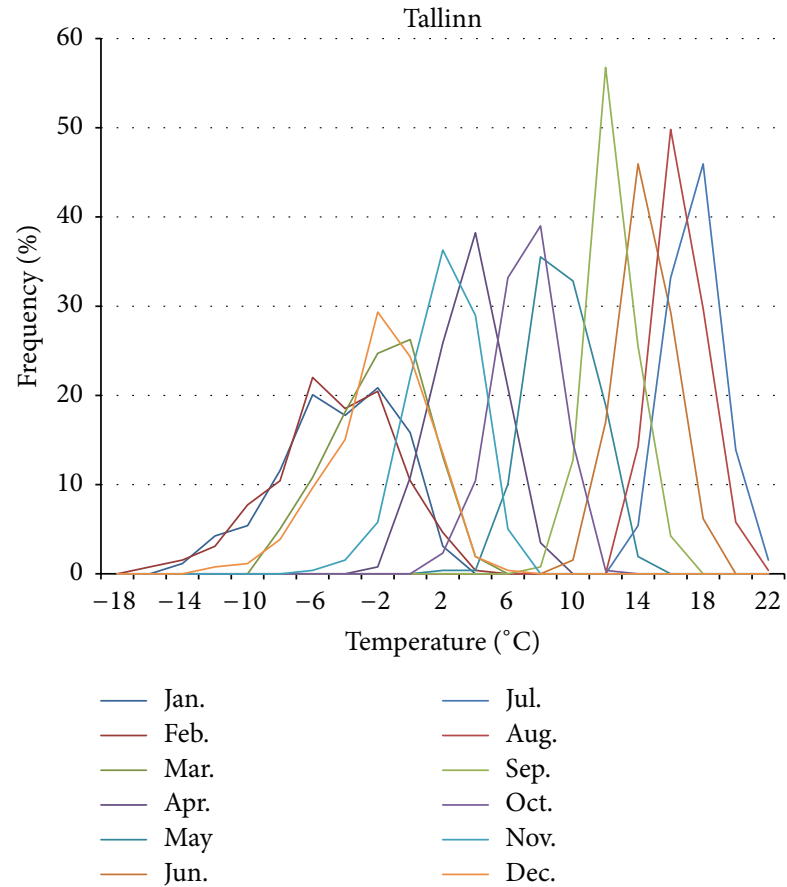

(a)

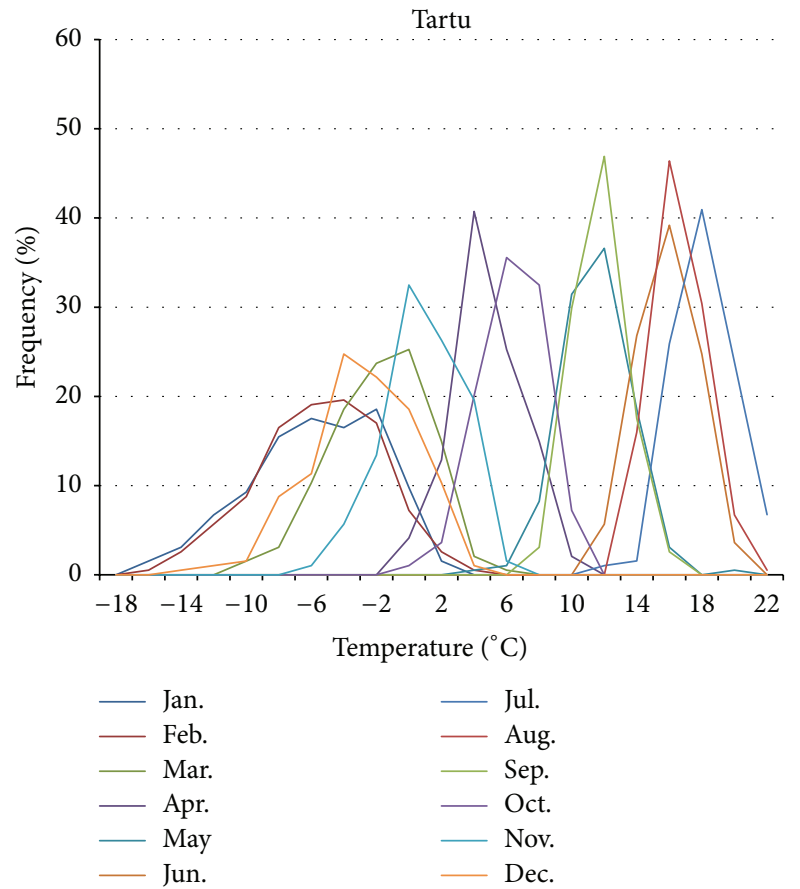

(b)

FIGURE 9: Frequency distributions of the average monthly air temperatures: (a) Tallinn, 1756-2014; (b) Tartu, 1821-2014.

September are similar; in addition, the distributions of the air temperatures in August and June are also quite similar.

Subsequently, we examined how the frequency distributions of the average monthly air temperatures have changed over the centuries. Figure 10 represents the frequency distributions of the average air temperatures both in Tallinn and Tartu in different periods month-wise. First, we tried to establish a change in the average situation by visual analysis of the charts. The change in the average air temperature is expressed by a change in the frequency distribution of the temperature.

In the case of January, a shift in the frequency distributions of air temperature toward higher temperatures is evident both in Tartu and in Tallinn (Figure 10(a)). In February, the tendency of a rise in air temperature is no longer strongly perceivable (Figure 10(b)). In March, a shift of about $2^{\circ} \mathrm{C}$ toward the temperature rise is visible, especially in the years 1901-2014 (Figure 10(c)). The average air temperatures of 

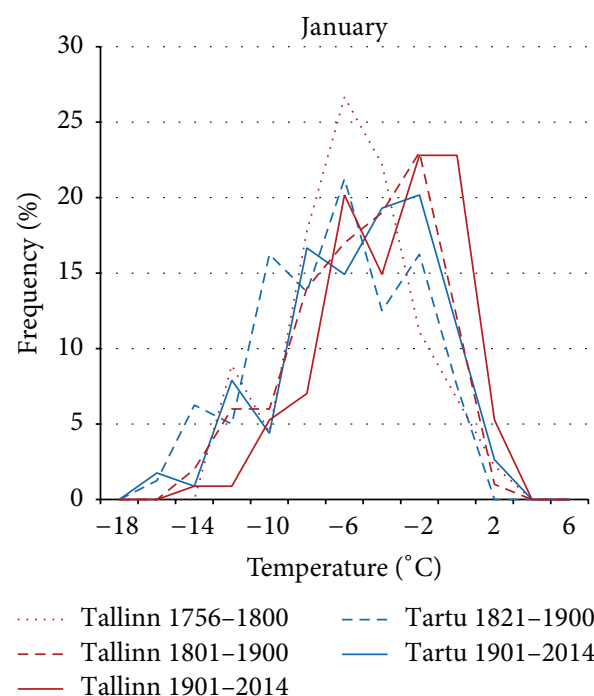

(a)

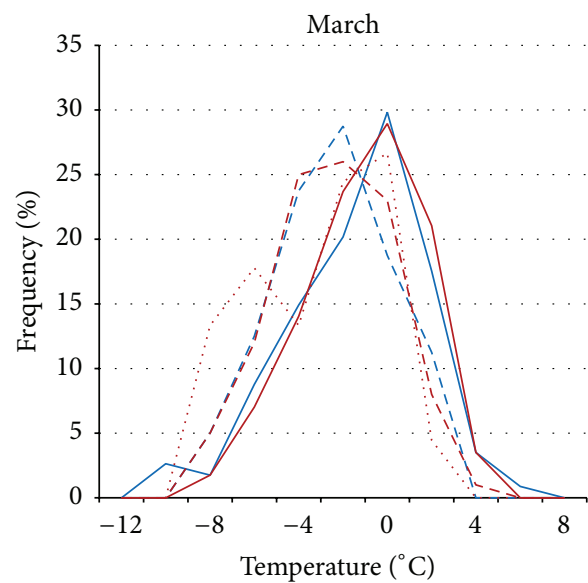

Tallinn 1756-1800

- - - Tallinn 1801-1900

- Tallinn 1901-2014

(c)

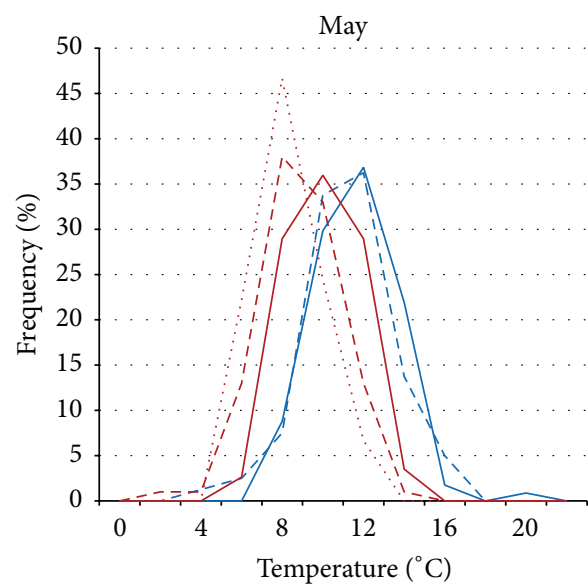

Tallinn 1756-1800

Tallinn 1801-1900

Tallinn 1901-2014

(e)

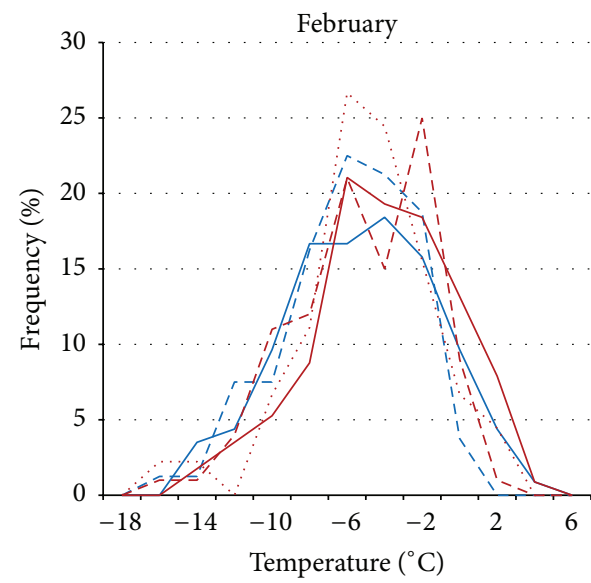

Tallinn 1756-1800 _ _- Tartu 1821-1900

Tallinn 1801-1900 _ Tartu 1901-2014

Tallinn 1901-2014

(b)

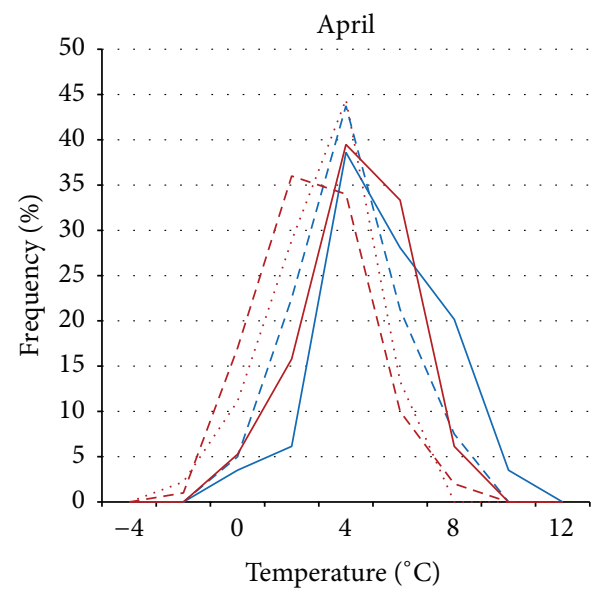

Tallinn 1756-1800 _ _ - Tartu 1821-1900

Tallinn 1801-1900 _ Tartu 1901-2014

_ Tallinn 1901-2014

(d)

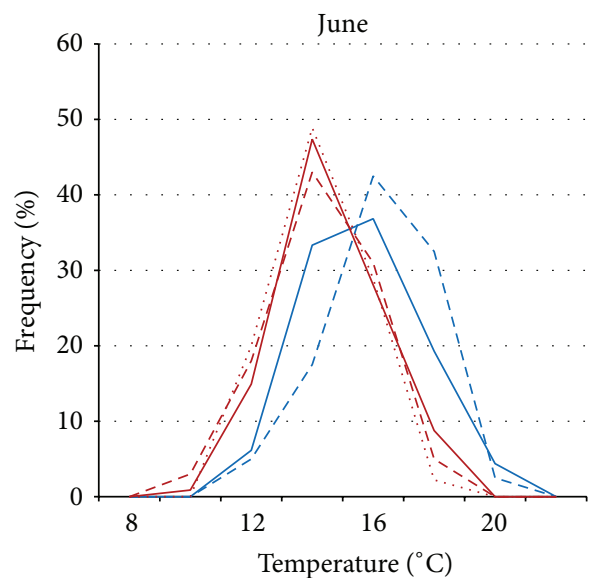

Tallinn 1756-1800 _ _ - Tartu 1821-1900

Tallinn 1801-1900 — Tartu 1901-2014

_ Tallinn 1901-2014

(f)

FIgURe 10: Continued. 

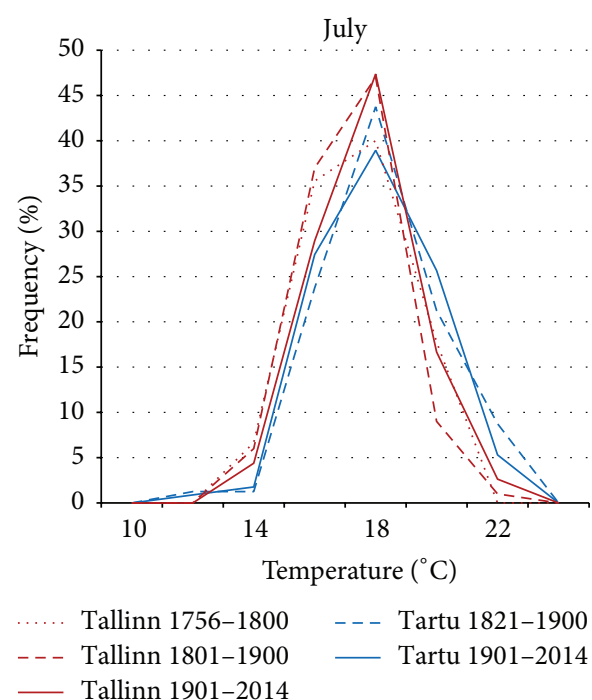

(g)
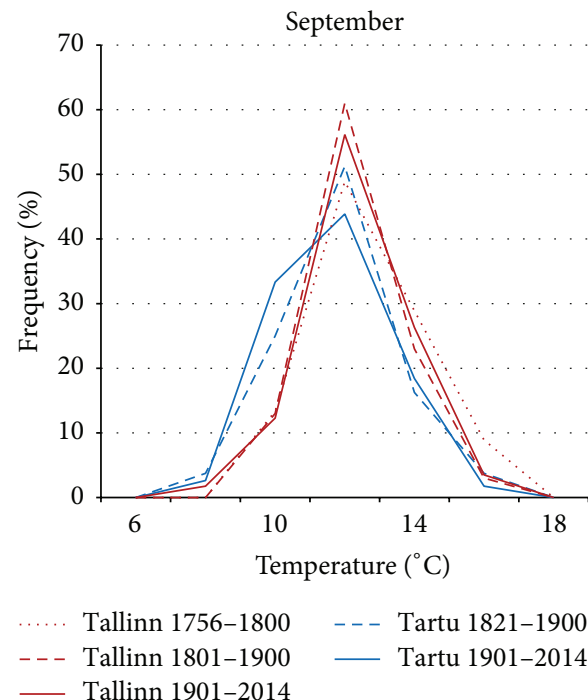

(i)
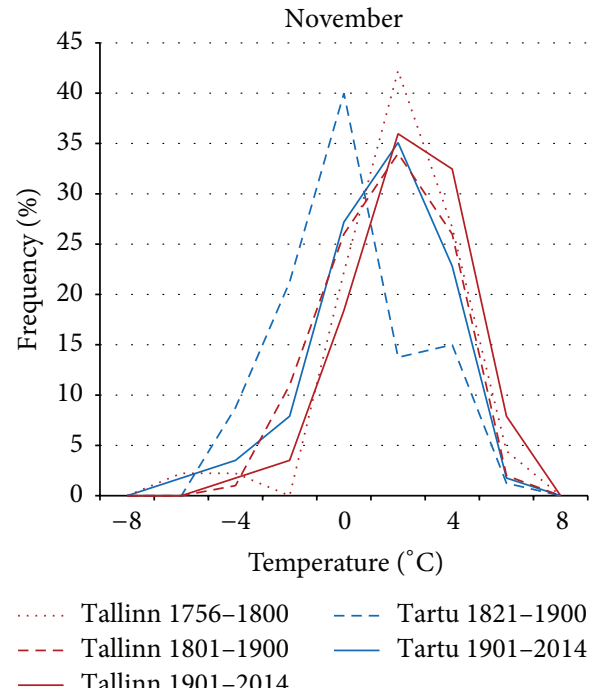

$(\mathrm{k})$
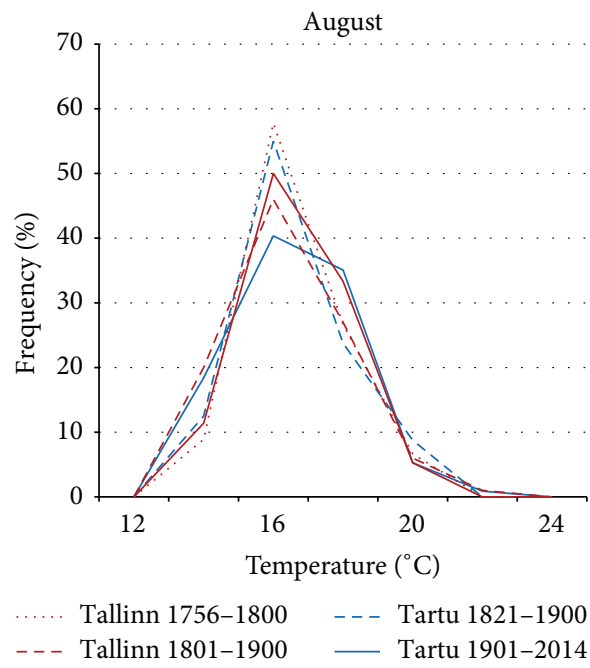

— Tallinn 1901-2014

(h)

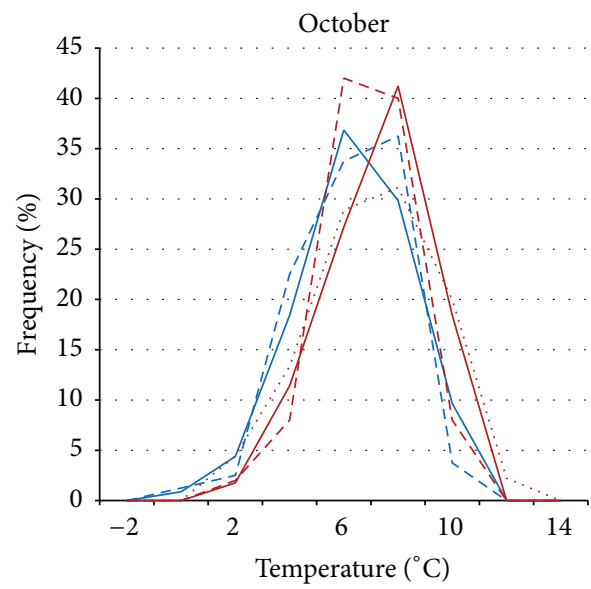

Tallinn 1756-1800 _ - - Tartu 1821-1900

Tallinn 1801-1900 — Tartu 1901-2014

Tallinn 1901-2014

(j)

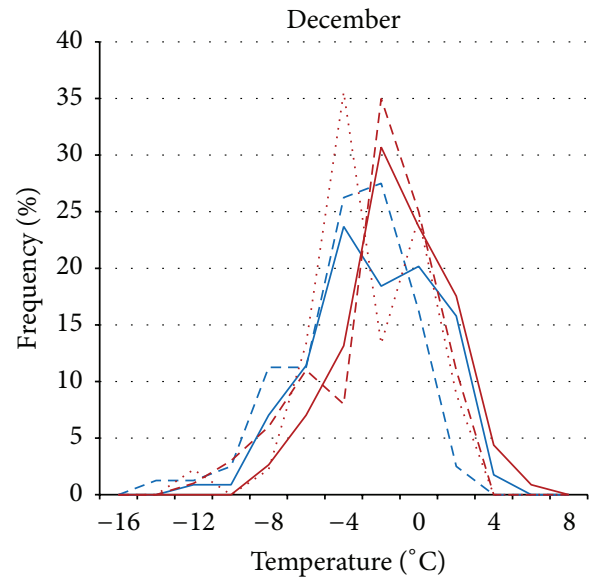

$\begin{array}{lll}\text {.... Tallinn 1756-1800 } & -- \text { Tartu 1821-1900 } \\ \text {-- Tallinn 1801-1900 } & \text { - Tartu 1901-2014 } \\ \text { - Tallinn 1901-2014 } & \end{array}$

(l)

FIGURE 10: Frequency distributions of the average air temperatures in Tallinn and Tartu in different months: (a) January; (b) February; (c) March; (d) April; (e) May; (f) June; (g) July; (h) August; (i) September; (j) October; (k) November; (l) December. 
April (Figure 10(d)) have become warmer in the years 19012014 compared to the previous periods. At the same time, the air temperatures in Tallinn in the 19th century were lower than the 18th century. In May, the air temperature in Tallinn has significantly risen in the past centuries while in Tartu, the rise is insignificant (Figure 10(e)). In June (Figure 10(f)), the average air temperatures in Tallinn have not changed in the past few centuries. However, in Tartu, the average air temperature in May has reduced. In July, the long-term changes in the air temperatures both in Tallinn and Tartu are insignificant (Figure 10(g)). In addition, in August (Figure 10(h)) and September (Figure 10(i)), no considerable changes have taken place in the average air temperatures. In October, the frequency distributions show a difference between the average air temperatures in Tallinn and Tartu, but there are only minor changes in the frequency distributions of the average air temperatures of various centuries (Figure 10(j)). In November, a significant shift in the frequency distributions of the air temperature in Tartu towards the positive temperatures is perceivable while the change is rather small in the case of Tallinn (Figure 10(k)). In the frequency distributions of the air temperatures in December, a minor shift toward the temperature rise is visible both in Tartu and in Tallinn (Figure 10(1)).

A visual assessment of the frequency distributions allows the assessment of the general nature of changes that have taken place; however, it gives no information on whether the changes hold any statistical relevance. It becomes evident from Figure 10 that the distribution of the average monthly temperatures can be regarded as close to a normal distribution in the first approximation. Thus, the methods of verification of statistical hypotheses dealing with random variables with normal distribution can be used.

In order to check the statistical relevance of the change of the average temperatures of various periods, Welch's $t$-test was used [14]. Let us assume that the air temperature of a period has a normal distribution characterized by average temperature $\mu_{1}$ and the temperature dispersion $\sigma_{1}{ }^{2}$. The average temperature for another period compared is $\mu_{2}$ and the temperature dispersion is $\sigma_{2}{ }^{2}$. The values of the average temperatures and dispersions are unknown to us. For the period $n_{1}$ and the other period $n_{2}$, we have the measured values of temperature; these values can be regarded as a sample from a time-series of distribution of temperatures. The $t$-test helps to determine whether the difference between the average temperatures $\bar{x}_{1}$ and $\bar{x}_{2}$ obtained from the measured values is statistically relevant or not.

Let us formulate a zero hypothesis that states the average temperatures for the compared periods to be not risen, $H_{0}: \mu_{1}-\mu_{2} \leq 0$. An alternative hypothesis is that the average temperatures have risen, $H_{1}: \mu_{1}-\mu_{2}>0$. For calculation of the test statistic, we used the below equation:

$$
t_{0}=\frac{\bar{x}_{1}-\bar{x}_{2}}{\sqrt{s_{1}^{2} / n_{1}+s_{2}^{2} / n_{2}}},
$$

where $s_{1}$ and $s_{2}$ are standard deviations of measured temperatures (samples).

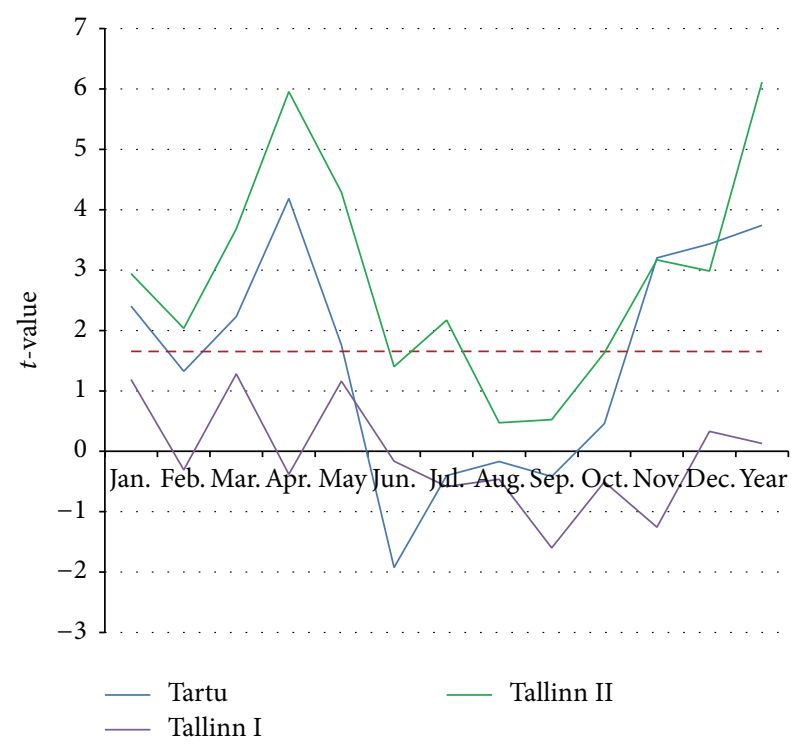

FIGURE 11: A verified $t$-test of the hypothesis of the air temperature change in Tallinn and Tartu. Significance level 0.05. The zero hypothesis (average temperature has not risen) is valid in the critical area of the parameter (below the dashed line). Comparison periods of the average temperatures: Tartu: 1901-2014 in relation to the period of 1821-1900; Tallinn I: the average temperatures of the period of 1801-1900 in relation to the period of 1756-1800; Tallinn II: the average temperatures of the period of 1901-2014 in relation to the period of 1801-1900.

A zero hypothesis can be rejected if $t_{0}>t_{\alpha, v} \cdot t_{\alpha, \nu}$ is a value of Student's $t$-function corresponding to significance level or probability of error $\alpha$, and the number of degrees of freedom $\nu$. The number of degrees of freedom $v$ is calculated with

$$
v=\frac{\left(s_{1}{ }^{2} / n_{1}+s_{2}{ }^{2} / n_{2}\right)^{2}}{\left(s_{1}{ }^{2} / n_{1}\right)^{2} /\left(n_{1}-1\right)+\left(s_{2}{ }^{2} / n_{2}\right)^{2} /\left(n_{2}-1\right)} .
$$

By taking the value of significance level $\alpha=0.05$, it was determined whether the average monthly and yearly air temperatures in Tartu and Tallinn had risen. The calculations demonstrate (Figure 11) that the air temperatures in Tallinn in the 19th century have not been raised as compared to the 18 th century. The changes in the 20th century (together with the beginning of the 21st century), however, are considerable compared to those of the 19th century. The temperature rise is considerable from November to May, except in February, when the temperature rise was evident; however, in Tartu, (inland) the temperature rise has no significant value. From June to October, the zero hypothesis stated zero temperature change compared to the 18th century that remained valid in the case of Tartu. In June, a significant fall in the average temperature was observed. However, in the case of Tallinn, no significant temperature rise has occurred in June and from August to October. At the same time, the rise in the average annual temperatures in relation to the 19th century is statistically relevant (significance level, $\alpha=0.05$ ). 


\section{Conclusions}

By using a long time-series of average monthly air temperatures in Tallinn and Tartu, as reconstructed by Tarand et al. [8] and supplemented by the results of measurement from the Estonian Weather Service, the change and variations of air temperatures for various periods of time were analyzed. The temperature changes for a short period may not be extrapolated to a longer period as shown in Figure 3, where several periods have existed for a longer time during which the average annual air temperature has suddenly risen and then fallen.

When analyzing the change in the air temperature, it should be taken into account that the temperature changes in a particular locality do not coincide with the global change in air temperature, which are not homogeneous either throughout the year.

Average yearly and monthly air temperatures in Estonia vary to greater extent during long-term periods (Table 2). Hence, the temperatures are observed as random values in this research. Random value can be characterized with frequency distribution beside its average. Based on the frequency distribution, it is possible to estimate the occurrence of different air temperatures.

The changes of average air temperatures may be caused by specific systematic causes as well as by random factors (as a random combination of several common influences). By using Welch's $t$-test of statistical hypothesis, it has been checked whether the long-term period average monthly and yearly air temperatures changes can be explained by unequal variances (null hypothesis). We can speak about the increase of average air temperatures in cases when the empirical values of $t$-statistics of air temperatures measured at observations are higher than the critical value of $t$-statistics. In cases when the empirical value of $t$-statistics is lower than the critical value, we cannot confirm the statement that average air temperatures have risen. As the result of the analysis, it has become evident that the average yearly air temperature in Tallinn as well as Tartu has risen (significance level 0.005). At the same time it cannot be said about the average monthly air temperatures all of months. By analyzing the frequencies of occurrence of the average monthly air temperatures for various periods, it was found that, in Estonia, a significant rise in air temperature in the past century in the coastal city of Tallinn can be observed in autumn and spring, whereas in midwinter, in February, the rise is minimal. Welch's $t$-test shows (Figure 11) that in Estonian inland (Tartu), a rise in air temperature in the past century cannot be observed in the period from May to October (significance level 0.05).

Our findings show that the air temperature has risen in Estonia in winter and early spring; however, in the summer, no significant temperature rise has taken place. According to the hypothesis, albedo is one of the essential factors affecting the ground's thermal balance and thereby the air temperature. The conditions of Estonia depend substantially on the icing of the Baltic Sea and the presence of the snow cover. The correlation coefficients based on the data from 1962-2002 between the mean air temperature of the period DecemberFebruary and the maximum ice extent in the Baltic Sea are -0.93 (Tallinn) and -0.90 (Tartu) [17]. The correlation coefficients between the mean air temperature of the period November-March and winter snow cover duration are -0.88 (Tallinn) and -0.83 (Tartu) [17]. Thus, global warming in the conditions of Estonia can boost the temperature regime by changing the ice and snow conditions. This would also explain the rising trends of air temperature in Estonia as presented in Figure 6. The follow-up research may contribute to the clarification of this matter.

\section{Conflict of Interests}

The author declares that there is no conflict of interests regarding the publication of this paper.

\section{References}

[1] IPCC, "Climate change 2001: the scientific basis," in Contribution of Working Group I to the Third Assessment Report of the Intergovernmental Panel on Climate Change, J. T. Houghton, Y. Ding, D. J. Griggs et al., Eds., p. 881, Cambridge University Press, Cambridge, UK, 2001.

[2] D. L. Hartmann, A. M. G. Klein Tank, M. Rusticucci et al., "Observations: atmosphere and surface," in Climate Change 2013: The Physical Science Basis. Contribution of Working Group I to the Fifth Assessment Report of the Intergovernmental Panel on Climate Change, T. F. Stocker, D. Qin, G.-K. Plattner et al., Eds., pp. 159-254, Cambridge University Press, Cambridge, UK, 2013.

[3] A. Tarand and A. Eensaar, "Air temperature," in Country Case Study on Climate Change Impacts and Adaptation Assessments in the Republic of Estonia, pp. 17-21, Stockholm Environment Institute-Tallinn, Tallinn, Estonia, 1998.

[4] A. Tarand and P. Ø. Nordli, "The tallinn temperature series reconstructed back half a millennium by use of proxy data," Climatic Change, vol. 48, no. 1, pp. 189-199, 2001.

[5] J. Jaagus and K. Mändla, "Climate change scenarios for Estonia based on climate models from the IPCC Fourth Assessment Report," Estonian Journal of Earth Sciences, vol. 63, no. 3, pp. 166-180, 2014.

[6] A. Tarand, "Meteoroloogilised vaatlused Eestis enne 1850. Aastat. Teaduse ajaloo küsimusi Eestist, VIII," Tallinn, Estonia, pp. 30-50, 1992.

[7] A. Tarand, 200 aastat professor C. L. Carpovi meteoroloogilistest vaatlustest, EGS Aastaraamat, Tallinn, Estonia, 1979.

[8] A. Tarand, J. Jaagus, and A. Kallis, Eesti kliima minevikus ja tänapäeval, Tartu Ülikooli Kirjastus, Tartu, Estonia, 2013.

[9] A. Tarand and P. Kuiv, "The beginning of the rye harvest-a proxi indicator of summer climate in the Baltic area," in European Paleoclimate and Man, 8, pp. 61-72, Gustav Fischer, Stuttgart, Germany, 1994.

[10] A. Tarand, Tallinnas mõõdetud õhutemperatuuri aegrida, vol. 93 of Publicationes Geophysicales Universitatis Tartuensis, 2003.

[11] Eesti Meteoroloogia Aastaraamat 2013, Keskkonnaagentuur, Tallinn, Estonia, 2014.

[12] H. Meitern, Esimesed kestvamad ilmavaatlused Tartus 18211834, Teaduse Ajaloo Lehekülgi Eestist VIII, Tallinn, Estonia, 1992.

[13] O. Kärner and H. Meitern, Õhutemperatuuri muutustest Tartus viimase 200 aasta jooksul, vol. 50, Publicationes Geophysicales Universitatis Tartuensis, 2006. 
[14] C. Montgomery Douglas and C. R. Runge George, Applied Statistics and Probability for Engineers, E Wiley \& Sons, New York, NY, USA, 5th edition, 2011.

[15] D. E. Parker, T. P. Legg, and C. K. Folland, "A new daily central England temperature series, 1772-1991," International Journal of Climatology, vol. 12, pp. 317-342, 1992.

[16] Met Office Hadley Centre Central England Temperature Data, http://www.metoffice.gov.uk/hadobs/hadcet/data/download .html.

[17] H. Tooming and J. Kadaja, Eds., Handbook of Estonian Snow Cover, Estonian Meteorological and Hydrological Institute, Tallinn, Estonia, 2006. 

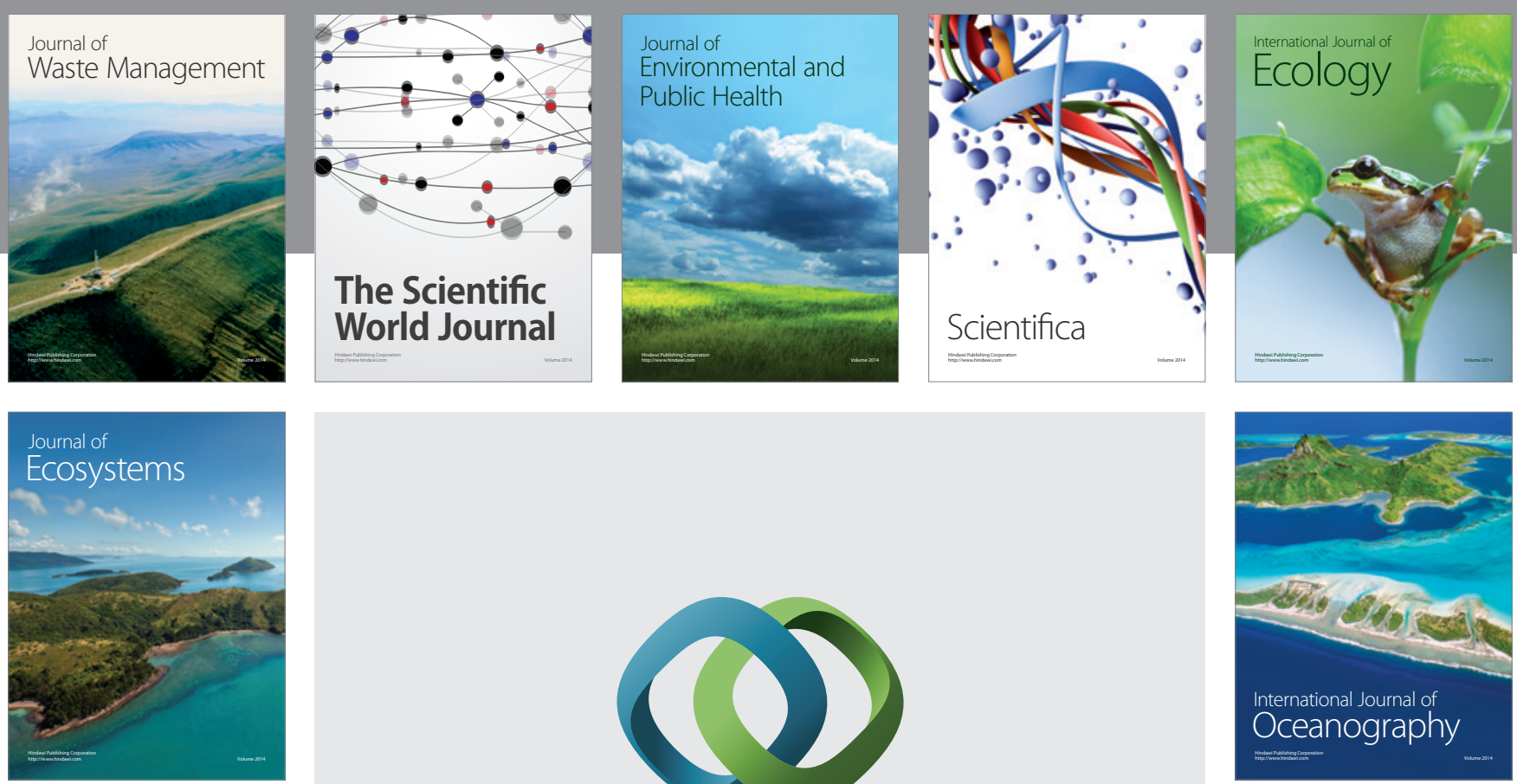

The Scientific World Journal
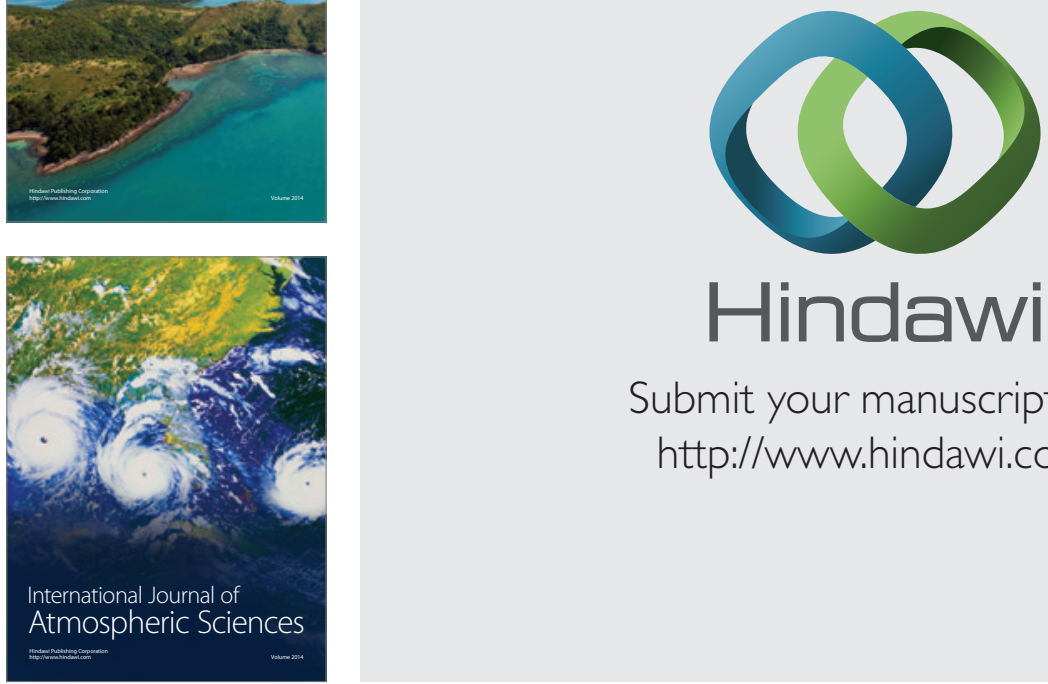

\section{Hindawi}

Submit your manuscripts at

http://www.hindawi.com
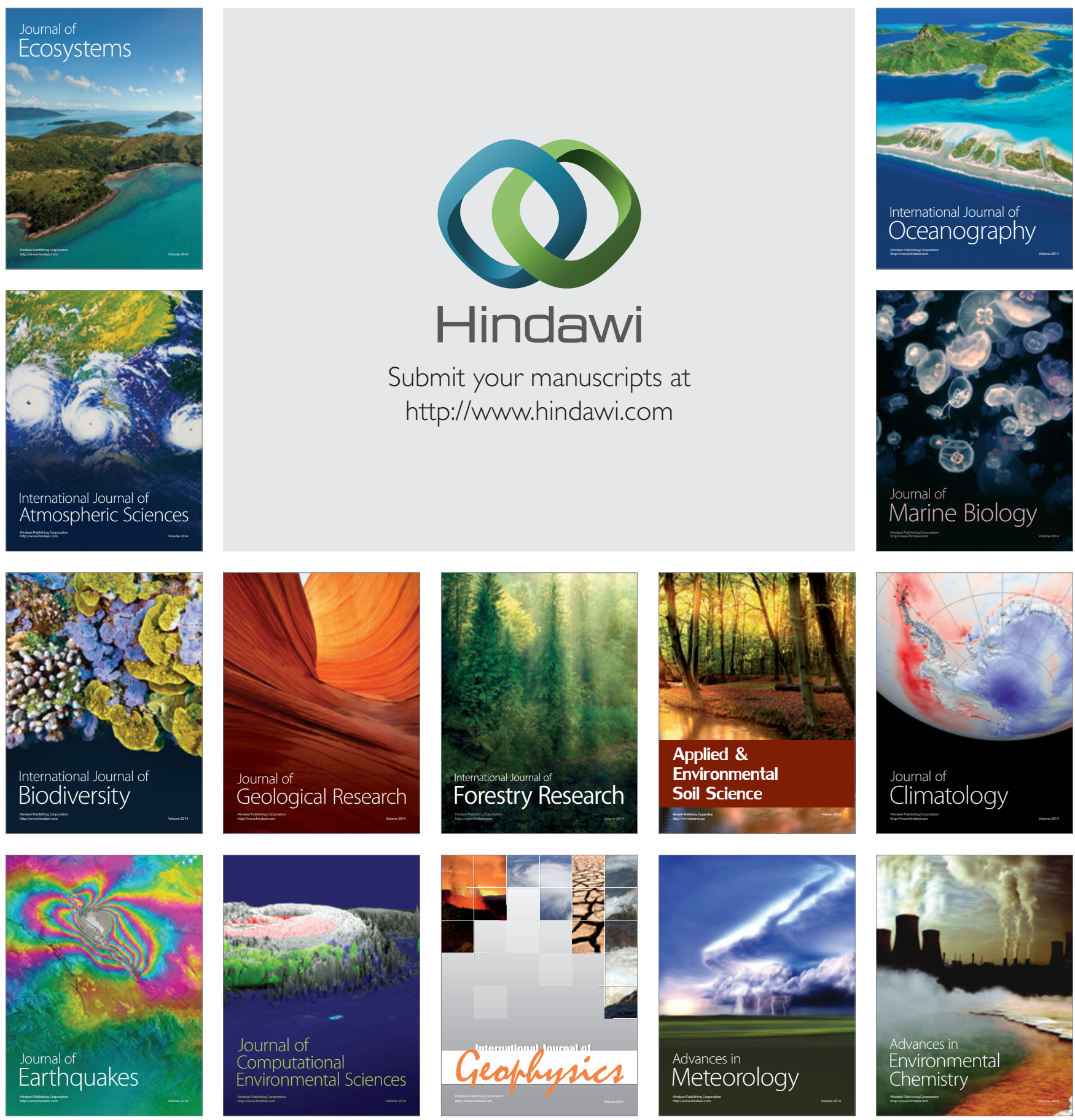